Article

\title{
Iron Oxide/Chitosan Magnetic Nanocomposite Immobilized Manganese Peroxidase for Decolorization of Textile Wastewater
}

\author{
Saifeldin M. Siddeeg ${ }^{1,2}{ }^{\oplus}$, Mohamed A. Tahoon ${ }^{1}\left(\mathbb{D}\right.$, Wissem Mnif ${ }^{3,4}\left({ }^{\circ}\right.$ and \\ Faouzi Ben Rebah 1,5,*(i) \\ 1 Department of Chemistry, College of Science, King Khalid University, \\ P.O. Box 9004, Abha 61413, Saudi Arabia; saif.siddeeg@gmail.com (S.M.S.); \\ tahooon_87@yahoo.com (M.A.T.) \\ 2 Chemistry and Nuclear Physics Institute, Atomic Energy Commission, \\ P.O. Box 3001, Khartoum 11111, Sudan \\ 3 Department of Chemistry, Faculty of Sciences and Arts in Balgarn, University of Bisha, \\ P.O. BOX 199, Bisha 61922, Saudi Arabia; w_mnif@yahoo.fr or wmoneef@ub.edu.sa \\ 4 LR11-ES31 Laboratory of Biotechnology and Valorisation of Bio-Geo Resources, Higher Institute of \\ Biotechnology of Sidi Thabet, BiotechPole of Sidi Thabet, University of Manouba, Biotechpole Sidi Thabet, \\ Ariana 2020, Tunisia \\ 5 Higher Institute of Biotechnology of Sfax (ISBS), Sfax University, P.O. Box 263, Sfax 3000, Tunisia \\ * Correspondence: benrebahf@yahoo.fr
}

Received: 19 November 2019; Accepted: 15 December 2019; Published: 18 December 2019

check for updates

\begin{abstract}
Because of its effectiveness in organic pollutant degradation, manganese peroxidase $(\mathrm{MnP})$ enzyme has attracted significant attention in recent years regarding its use for wastewater treatment. Herein, MnP was extracted from Anthracophyllum discolor fungi and immobilized on the surface of magnetic nanocomposite $\mathrm{Fe}_{3} \mathrm{O}_{4} /$ chitosan. The prepared nanocomposite offered a high surface area for $\mathrm{MnP}$ immobilization. The influence of several environmental factors like temperature, $\mathrm{pH}$, as well as storage duration on the activity of the extracted enzyme has been studied. Fourier transmission infrared spectroscopy (FT-IR), scanning electron microscope (SEM), $X$-ray diffraction (XRD), and transmission electron microscope (TEM) techniques were used for the characterization of the prepared $\mathrm{MnP} / \mathrm{Fe}_{3} \mathrm{O}_{4} /$ chitosan nanocomposite. The efficiencies of the prepared $\mathrm{MnP} / \mathrm{Fe}_{3} \mathrm{O}_{4} /$ chitosan nanocomposite for the elimination of reactive orange 16 ( $\left.\mathrm{RO} 16\right)$ and methylene blue (MB) industrial dyes were determined. According to the results, the immobilization of $\mathrm{MnP}$ on $\mathrm{Fe}_{3} \mathrm{O}_{4} /$ chitosan nanocomposite increases its capacity to decolorize $\mathrm{MB}$ and $\mathrm{RO} 16$. This nanocomposite allowed the removal of $96 \% \pm 2 \%$ and $98 \% \pm 2 \%$ of $\mathrm{MB}$ and $\mathrm{RO} 16$, respectively. The reusability of the synthesized nanocomposite was studied for five successive cycles showing the ability to retain its efficiency even after five cycles. Thus, the prepared $\mathrm{MnP} / \mathrm{Fe}_{3} \mathrm{O}_{4} /$ chitosan nanocomposite has potential to be a promising material for textile wastewater bioremediation.
\end{abstract}

Keywords: bioremediation; nanocomposites; chitosan; enzymes; microorganisms

\section{Introduction}

Urbanization and contamination of surface drinking water resources have led to a crucial problem concerning the provision of safe water supplies in our contemporary world [1]. Uncontrolled discharges of municipal and industrial wastes in the environment can lead to the introduction of high concentrations of potentially toxic pollutants into water resources. Among the most harmful types of wastewater released are textile effluents that contain many dangerous artificial dyes like reactive 
orange 16 (RO 16) and methylene blue (MB). Due to its low prices, cationic dye MB is easily acquired and considered to be one of the most popular clothing colorants [2]. The industrial release of MB can disrupt ecosystem balance and damage the environment, due to its carcinogenic effects $[3,4]$. These effects are accompanied by several symptoms including severe headaches, skin irritation, and acute diarrhea [5]. RO 16 is an anionic azo dye widely used in the dyeing process [6]. The discharge of RO 16 effluent into natural water bodies can cause many problems, such as the reduction of photosynthetic activity by reducing sunlight transmission, negatively affecting the survival of aquatic life. Moreover, azo dyes have been shown to have mutagenic and carcinogenic effects $[7,8]$. Therefore, dyes must be removed before effluent discharge into the environment, as these molecules are hard to decompose in natural conditions ( $\mathrm{pH}$, temperature, etc.) or with conventional methods of treatment [9].

Electrochemical processes, exchanging ions, flotation, coagulation-flocculation, biotic processing, adsorption, reverse osmosis, as well as separation membranes, were widely used for the elimination of organic and inorganic pollutants [10-16]. However, the adsorption technique is the most widely used technique among all methods due to its cheapness, simplicity, and effectiveness [17]. Recently, researchers all over the world focused their efforts to introduce advanced adsorbents for wastewater treatment $[18,19]$. In this context, enzymes immobilized on solid supports were more widely used than free enzymes, since the immobilized enzyme can be easily separated from the reaction solution using various physical methods, such as centrifugation and filtration [20-22]. Interestingly, nanoparticles have emerged as an efficient tool to generate excellent support for enzymes offering various advantages. Benefits include the ability for a quick biomaterial recuperation using an external magnet, the higher amount of binding enzymes offered by magnetic iron oxide nanoparticles, the low operation price, and the reduction of both fouling and diffusion problems [23-29]. The existence of functional groups on nanoparticle surfaces is vital for their use as supports for bioactive component immobilization. Therefore, the existence of functional groups on the nanoparticle surfaces is intended to increase the potential for loading and stabilization of immobilized biomolecules. Generally, magnetic iron oxide nanoparticles were functionalized using synthetic and natural polymers such as chitosan. Chitosan, a type of hydrocolloid, is a biopolymer of linear positively charged polysaccharide. Highly reactive amino groups are present, increasing its adsorption capacity toward pollutants and allowing it to act as a bio-adsorbent [30]. Nevertheless, its high solubility in acids, tendency to undergo clumping, weak mechanical properties, and difficult separation, limit its use as an adsorbent alone. Chitosan is often used combined with other materials [31] and different forms of chitosan-based material gels, flakes, and powders were applied for the immobilization of many enzymes [32,33]. In recent years, manganese peroxidase $(\mathrm{MnP})$ has attracted the attention of researchers due to its ability to remove various organic contaminants including anthracene [34], phenanthrene [35] as well as polyaromatic hydrocarbons [36]. However, the use of $\mathrm{MnP}$ in the industrial applications faces some difficulties such as the low operational stability and the high cost, which can be overcome by the immobilization of the enzyme on the surface of nanocomposites [37].

In the present study we examined the efficiency of MnP enzyme extracted from the white root fungus of Anthracophyllum discolor toward the elimination of organic dyes RO 16 and MB from textile wastewater. The performance of the immobilized enzyme on the surface of magnetic nanocomposite $\mathrm{Fe}_{3} \mathrm{O}_{4} /$ chitosan was studied and compared to the free enzyme.

\section{Materials and Methods}

\subsection{Chemicals and Reagents}

Ferric chloride $\left(\mathrm{FeCl}_{3}\right)$ was provided through Xilong Scientific Co. (Shantou, China), while ferrous sulfate $\left(\mathrm{FeSO}_{4}\right)$, glutaraldehyde, and mineral oil were supplied from Sigma-Aldrich (Missouri, USA). The polymer chitosan, extracted from crab shells, was supplied from Winlab Company (Leicester, England). Acetone solvent, hydrogen peroxide, aqueous ammonia solution (33\%) and manganese sulfate $\left(\mathrm{MnSO}_{4}\right)$ were supplied via Al-Nasr Co., Helwan, Egypt. Methylene blue (MB), a cationic 
thiazine dye, and N-(3-Dimethylaminopropyl)- $\mathrm{N}^{\prime}$-ethylcarbodiimide hydrochloride were supplied via Merck (Hohenbrunn, Germany). Reactive orange 16 (RO 16), an anionic single azo dye, and Tween 80 were supplied from ACROS, Organics (Morris Plains, NJ, USA). All the used materials were of analytical grade and experimentally consumed as supplied without additional purification.

\subsection{MnP Extraction from Anthracophyllum Discolor}

$\mathrm{MnP}$ enzyme was extracted from the white root fungus $A$. discolor strain obtained from the microbiology laboratory (Biology Department, Mansoura University). The fungus was allowed to grow at $5{ }^{\circ} \mathrm{C}$ inside tubes in the presence of media containing $10 \mathrm{~g} / \mathrm{L}$ glucose (Merck, Hohenbrunn, Germany), $15 \mathrm{~g} / \mathrm{L}$ agar (Merck, Hohenbrunn, Germany) and $30 \mathrm{~g} / \mathrm{L}$ malt extract. The strain culture was then transferred to Petri dishes (Shanghai Joylab Medical Instruments Co., Ltd, Shanghai, China) and incubated for six days at $30{ }^{\circ} \mathrm{C}$. Subsequently, a Kirk media containing $0.06 \%(v / v)$ surfactant tween 80, $255 \mu \mathrm{M}$ of manganese sulfate (Al-Nasr Co., Helwan, Egypt) as MnP enzyme production inducer, and $33 \mathrm{~g}$ of wheat grains was prepared, and $95 \mathrm{~mL}$ of the Kirk media was inoculated by the mycelium of $A$. discolor and incubated at $30^{\circ} \mathrm{C}$ for 11 days. The partially purified MnP enzyme was obtained from the media after growth. The growth media was ultra-purified using three successive filters; $1.2 \mu \mathrm{m}$ Whatman glass filter (GE Healthcare Bio-Sciences, Pittsburgh, USA), an Amicon membrane, and $0.2 \mu \mathrm{m}$ mixed ester-cellulose filter (Merck, Hohenbrunn, Germany). The ultra-purified enzyme was tested for MnP activity via MBTH-DMAB (3-methyl-2-benzothiazolinone hydrazine and 3-(dimethylamino)benzoic acid) (Sigma Aldrich, Steinheim, Germany) method [38], in which $10 \mu \mathrm{L}$ hydrogen peroxide (10 mM) (Al-Nasr Co., Helwan, Egypt) was added to a mixture containing $\mathrm{MnSO}_{4}$ $(20 \mathrm{mM}, 30 \mu \mathrm{L})($ Al-Nasr Co., Helwan, Egypt), ultra-purified filtrate $(100 \mu \mathrm{L})$ (extracted from the white root fungus A. discolor ), MBTH $(1.5 \mathrm{mM}, 100 \mu \mathrm{L})$ (Sigma Aldrich, Steinheim, Germany), and DMAB $(6.6 \mathrm{mM}, 300 \mu \mathrm{L}$, buffer of succinate-lactate $(100 \mathrm{mM}, \mathrm{pH}=4.5,1460 \mu \mathrm{L})$. A purple color was produced and measured by absorbance. Thus, the enzymatic activity was determined by reading absorbance at $\lambda=590 \mathrm{~nm}$ and was calculated with the extinction coefficient $\left(\varepsilon=53,000 \mathrm{M}^{-1} \mathrm{~cm}^{-1}\right)$ according to the literature. The amount of enzyme needed for one $\mu \mathrm{M}$ of the reaction product in one minute is equal to one unit [38].

\subsection{Preparation of $\mathrm{Fe}_{3} \mathrm{O}_{4} /$ Chitosan Magnetic Nanocomposite}

Co-precipitation technique was used for $\mathrm{Fe}_{3} \mathrm{O}_{4}$ nanoparticle preparation. $\mathrm{FeSO}_{4}$ and $\mathrm{FeCl}_{3}$ solutions were mixed (1:2 molar ratios) and supplemented by aqueous ammonia with continuous stirring under nitrogen (Smgases, Beni Suef, Egypt) atmosphere for $30 \mathrm{~min}$. The resulted nanoparticles were recuperated using a permanent magnet (Risheng Magnets International Co.,Ltd, Ningbo, China) and washed several times with distilled water. The $\mathrm{Fe}_{3} \mathrm{O}_{4} /$ chitosan nanocomposite was prepared via reversed-phase suspension method in which $200 \mathrm{mg}$ of washed iron oxide nanoparticles were mixed with $55 \mathrm{~mL}$ of mineral oil (Sigma-Aldrich, Missouri, USA) containing $0.6 \mathrm{~mL}$ of tween 80 (Acros Organics, Morris Plains, NJ, USA). After that, 1\% (w/v) of chitosan (Winlab Company, Leicester, England) was added to the mixture. The synthesized $\mathrm{Fe}_{3} \mathrm{O}_{4} /$ chitosan nanocomposite was sonicated and stirred for $35 \mathrm{~min}$. The mixture was supplemented with $3.5 \mathrm{~mL}$ of $25 \%(w / v)$ glutaraldehyde solution (Sigma-Aldrich, St. Louis, MO, USA) and stirred for $5 \mathrm{~h}$. Finally, the synthesized $\mathrm{Fe}_{3} \mathrm{O}_{4} /$ chitosan nanocomposite was isolated using a magnet, washed many times using acetone, and dried at $45^{\circ} \mathrm{C}$ in a vacuum. The produced $\mathrm{Fe}_{3} \mathrm{O}_{4}$ nanoparticles and $\mathrm{Fe}_{3} \mathrm{O}_{4} /$ chitosan nanocomposite were characterized using different techniques including Fourier transform infrared (FT-IR) spectroscopy (Bruke EQUINOX 55, Karlsruhe, Germany), transmission electron microscope (TEM, Technai $\mathrm{G}^{2}$ F30, Hillsboro, USA), scanning electron microscope (SEM, LEO $1450 \mathrm{VP}$, England), as well as X-ray diffraction (XRD, Rigaku MiniFlex 600 X-ray, USA). 


\subsection{Immobilization of $\mathrm{MnP}$ on the $\mathrm{Fe}_{3} \mathrm{O}_{4} /$ Chitosan Nanocomposite}

$2 \mathrm{~mL}$ of phosphate buffer (Al-Nasr Co., Helwan, Egypt) $(0.04 \mathrm{M}, \mathrm{pH}=6)$ was used to disperse $50 \mathrm{mg}$ of nanocomposite in an ultrasonic bath at $4{ }^{\circ} \mathrm{C}$ to immobilize $\mathrm{MnP}$ on the $\mathrm{Fe}_{3} \mathrm{O}_{4}$ nanocomposite. Then, $0.6 \mathrm{~mL}$ of $2.5 \% \mathrm{~N}$-(3-dimethylaminopropyl)- $\mathrm{N}^{\prime}$-ethylcarbodiimide hydrochloride (Merck, Hohenbrunn, Germany) in $2 \mathrm{~mL}$ phosphate buffer was added to the previous solution and ultra-sonicated for a half-hour. The obtained mixture was stirred for $7 \mathrm{~h}$ at $1000 \mathrm{rpm}$ and $4{ }^{\circ} \mathrm{C}$. After that, the nanocomposite was collected with a permanent magnet (Risheng Magnets International Co.,Ltd, Ningbo, China) and washed several times in the phosphate buffer. For each $10 \mathrm{mg}$ of the nanocomposite, $250 \mu \mathrm{L}$ of the filtrate was added and stirred at $200 \mathrm{rpm}$ and $30{ }^{\circ} \mathrm{C}$ for $30 \mathrm{~min}$. Subsequently, the nanocomposite was collected by the magnet and washed by buffer solution $(\mathrm{pH}=4.5)$ of sodium acetate (Al-Nasr Co., Helwan, Egypt) $(50 \mathrm{mM})$ until the activity of the enzyme disappeared from the resulted solution. Finally, the obtained $\mathrm{MnP} / \mathrm{Fe}_{3} \mathrm{O}_{4} /$ chitosan nanocomposite was dried at $35^{\circ} \mathrm{C}$. The effect of various operating conditions including $\mathrm{pH}(3.5-9.5)$, temperature $\left(30-70{ }^{\circ} \mathrm{C}\right)$ for $1 \mathrm{~h}$, and storage duration at $20{ }^{\circ} \mathrm{C}$ (for 14 days) on immobilized $\mathrm{MnP}$ as well as free $\mathrm{MnP}$ were studied. Each experiment was performed in triplicate.

\subsection{Wastewater Treatment Experiment}

In order to study the removal efficiency of $\mathrm{MnP}, \mathrm{Fe}_{3} \mathrm{O}_{4} /$ chitosan nanocomposite, and $\mathrm{MnP} / \mathrm{Fe}_{3} \mathrm{O}_{4} /$ chitosan nanocomposite toward dyes $\mathrm{RO} 16$ and $\mathrm{MB}$, synthetic wastewater containing $50 \mathrm{mg} / \mathrm{L}$ of each dye was prepared. A $100 \mathrm{~mL}$ Erlenmeyer flask (Sigma Aldrich, Steinheim, Germany) was used in the adsorption experiment, in which $50 \mathrm{~mL}$ of synthetic wastewater was mixed with $10 \mathrm{mg}$ of $\mathrm{Fe}_{3} \mathrm{O}_{4} /$ chitosan nanocomposite, and $\mathrm{MnP} / \mathrm{Fe}_{3} \mathrm{O}_{4} /$ chitosan nanocomposite. In the case of the free $\mathrm{MnP}$, the same volume as the immobilized ultra-purified filtrate was used. The wastewater decolorization experiment was conducted at $\mathrm{pH}$ 7, temperature $27^{\circ} \mathrm{C}, 100 \mathrm{rpm}$ and, for a contact time ranged from 10 to $50 \mathrm{~min}$. The dye concentrations before and after adsorption were analyzed using a UV/VIS spectrophotometer (SHIMADZU, UV-2401pc, Addison, IL, USA) at $495 \mathrm{~nm}$ and $660 \mathrm{~nm}$ for RO 16 and $\mathrm{MB}$, respectively. After each experiment, the magnetic nanocomposites were collected using a permanent magnet. Each experiment was performed in triplicate.

\section{Results and Discussion}

\subsection{Characterization of the Synthesized Nanocomposite}

Different techniques for characterization including XRD, SEM, FT-IR, and TEM were used to identify chitosan, synthesized $\mathrm{Fe}_{3} \mathrm{O}_{4}$ nanoparticles, and synthesized $\mathrm{Fe}_{3} \mathrm{O}_{4}$ /chitosan nanocomposite. SEM images of $\mathrm{Fe}_{3} \mathrm{O}_{4}$ and $\mathrm{Fe}_{3} \mathrm{O}_{4}$ /chitosan nanoparticles are presented in Figure 1a,b, respectively. SEM showed a homogeneous distribution of $\mathrm{Fe}_{3} \mathrm{O}_{4}$ nanoparticles, which is related to the presence of chitosan offering high surface for the immobilization of the MnP enzyme. Furthermore, a spherical shape of iron oxide nanoparticles and a size less than $35 \mathrm{~nm}$ were determined from the SEM image. Based on the TEM images (Figure 1c, d for $\mathrm{Fe}_{3} \mathrm{O}_{4}$ and $\mathrm{Fe}_{3} \mathrm{O}_{4} /$ chitosan, respectively), the prepared nanoparticles showed uniform spherical morphology with crystalline structure.

FT-IR Bands for $\mathrm{Fe}_{3} \mathrm{O}_{4}$, chitosan and $\mathrm{Fe}_{3} \mathrm{O}_{4}$ /chitosan nanocomposite are presented in Figure 2a. According to the FT-IR of the magnetic $\mathrm{Fe}_{3} \mathrm{O}_{4}$ nanoparticles, the $465 \mathrm{~cm}^{-1}$ band beside the $579 \mathrm{~cm}^{-1}$ band denotes octahedral and tetrahedral sites $\mathrm{Fe}-\mathrm{O}$ bands [39]. Several bands were noticed representing the different functional groups of chitosan and $\mathrm{Fe}_{3} \mathrm{O}_{4} /$ chitosan nanocomposite. The bands include stretching and bending $\mathrm{C}=\mathrm{O}$ vibrations with $1530 \mathrm{~cm}^{-1}$ and $1626 \mathrm{~cm}^{-1}$, wide amino and $\mathrm{O}-\mathrm{H}$ vibrations with an interval of $3000 \mathrm{~cm}^{-1}-3620 \mathrm{~cm}^{-1}$ and vibrational C-O band with $1069 \mathrm{~cm}^{-1}$ [40]. Additionally, the presence of $\mathrm{Fe}-\mathrm{O}$ bands in the IR spectrum of $\mathrm{Fe}_{3} \mathrm{O}_{4} /$ chitosan nanocomposite indicates the in-situ structure of $\mathrm{Fe}_{3} \mathrm{O}_{4}$ nanoparticles inside $\mathrm{Fe}_{3} \mathrm{O}_{4} /$ chitosan nanocomposite. 


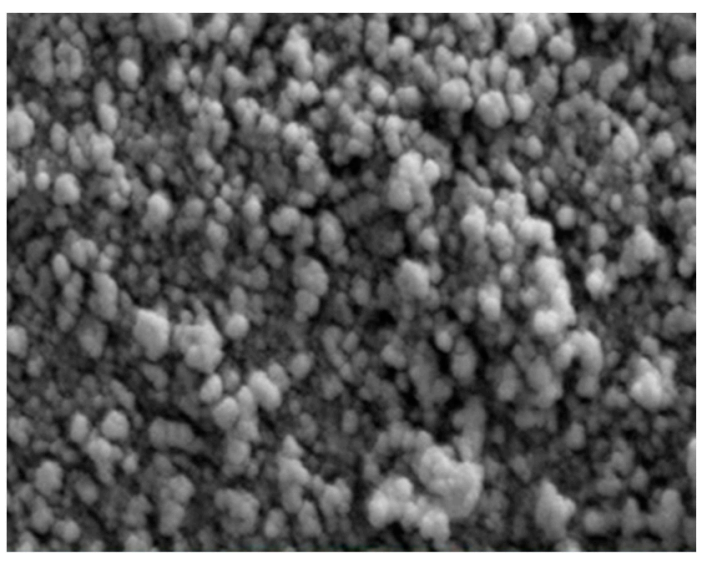

(a)

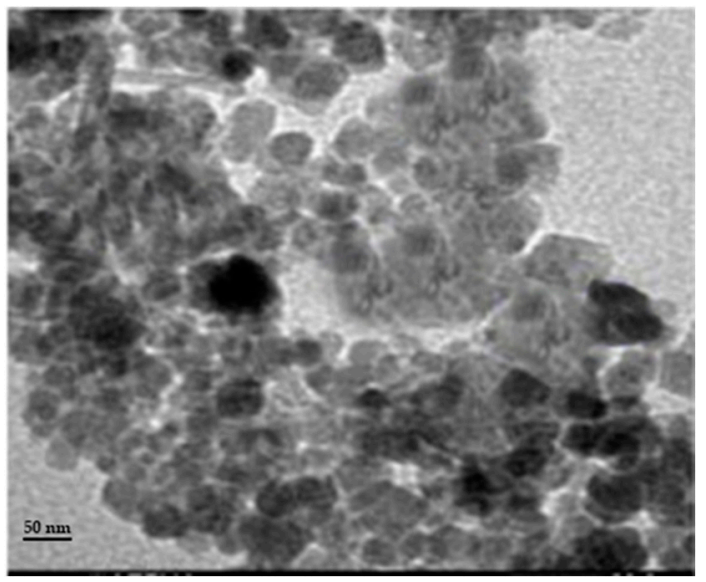

(c)

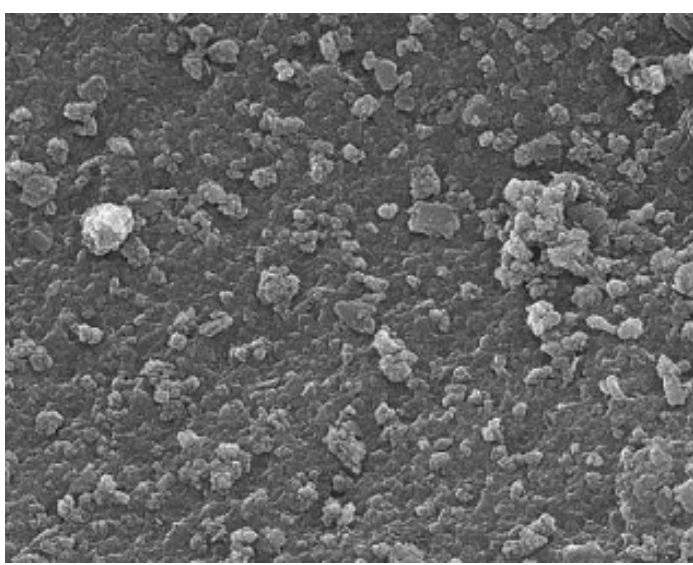

(b)

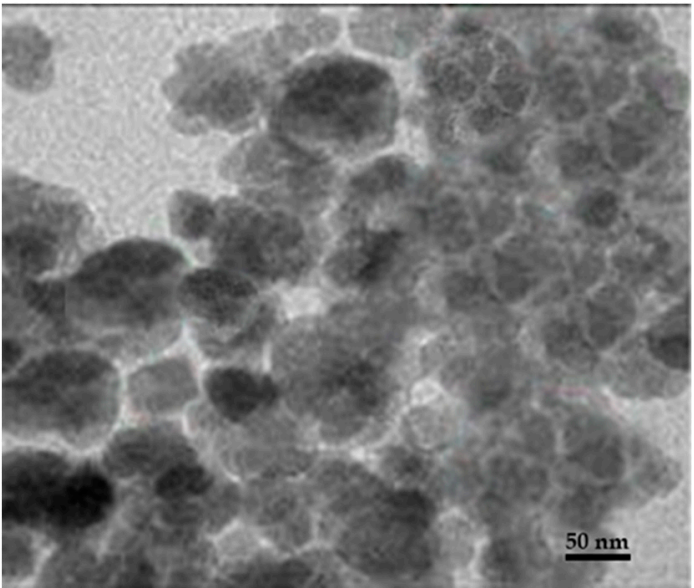

(d)

Figure 1. (a) SEM image of $\mathrm{Fe}_{3} \mathrm{O}_{4}$; (b) SEM image of $\mathrm{Fe}_{3} \mathrm{O}_{4} /$ chitosan; (c) TEM image of $\mathrm{Fe}_{3} \mathrm{O}_{4}$; (d) TEM image of $\mathrm{Fe}_{3} \mathrm{O}_{4} /$ chitosan.

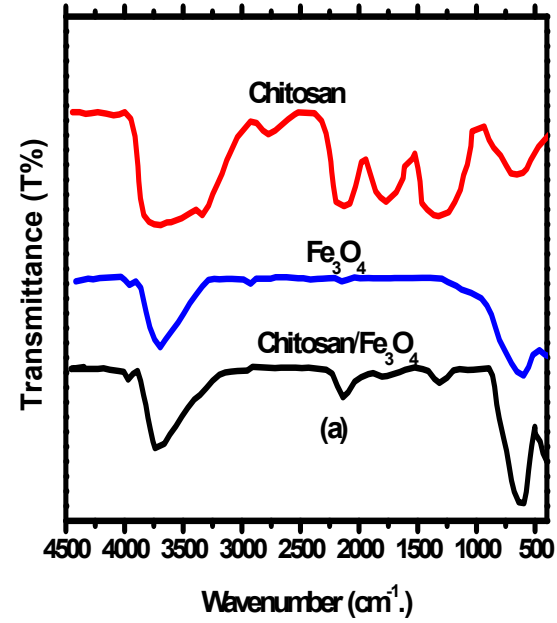

(a)

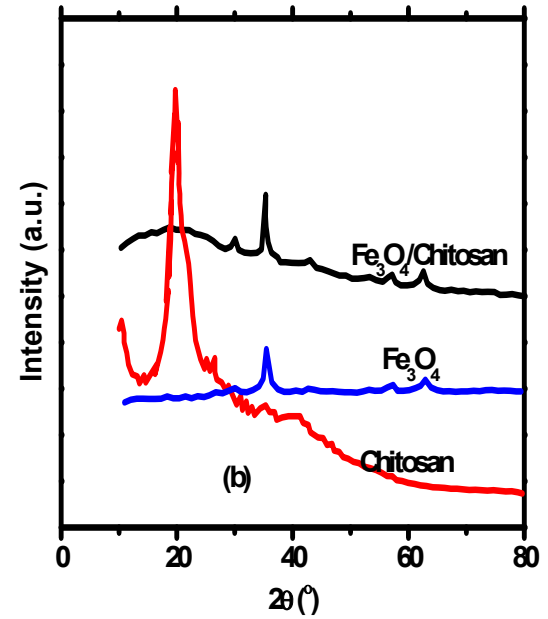

(b)

Figure 2. (a) FT-IR of chitosan, $\mathrm{Fe}_{3} \mathrm{O}_{4}$ nanoparticles and $\mathrm{Fe}_{3} \mathrm{O}_{4}$ /chitosan nanocomposites; (b) XRD chitosan, $\mathrm{Fe}_{3} \mathrm{O}_{4}$ nanoparticles and $\mathrm{Fe}_{3} \mathrm{O}_{4}$ /chitosan nanocomposites.

XRD pattern of $\mathrm{Fe}_{3} \mathrm{O}_{4}$ nanoparticles, chitosan, and $\mathrm{Fe}_{3} \mathrm{O}_{4} /$ chitosan nanocomposite is shown in Figure $2 \mathrm{~b}$. The XRD peaks of chitosan appeared at $20.7^{\circ}$, while peaks appeared at $62.89^{\circ}, 57.26^{\circ}$, 
$53.56^{\circ}, 43.27^{\circ}, 35.68^{\circ}$, and $30.24^{\circ}$ for $\mathrm{Fe}_{3} \mathrm{O}_{4}$ nanoparticles indicating a pure spinal structure of the prepared nanoparticles. Furthermore, the appearance of the $\mathrm{Fe}_{3} \mathrm{O}_{4}$ nanoparticles peaks with a small shift in $\mathrm{Fe}_{3} \mathrm{O}_{4} /$ chitosan nanocomposite XRD indicates the spinel structure of the nanocomposite. The FT-IR of nanocomposite has a band at $21.7^{\circ}$ representing chitosan. A size of $26 \mathrm{~nm}$ was approved for $\mathrm{Fe}_{3} \mathrm{O}_{4}$ nanoparticles, and $\mathrm{Fe}_{3} \mathrm{O}_{4} /$ chitosan nanocomposite calculated by the application of Debye-Scherrer's equation.

\subsection{Purified MnP Measured Activity}

The activity of MnP enzyme in the $A$. discolor filtrate was measured, as described in the experimental section according to the literature [38]. The MnP activity was found to be $4000 \mathrm{U} / \mathrm{L}$, which is considered as an excellent result for the ultra-purified filtrate.

\subsection{The Temperature and $p H$ Effect on the Immobilized and Free MnP Activity}

The immobilized $\mathrm{MnP}$ on the surface of $\mathrm{Fe}_{3} \mathrm{O}_{4} /$ chitosan magnetic nanocomposite and the free $\mathrm{MnP}$ activities were examined at various temperatures and $\mathrm{pHs}$. The working temperature ranged from $30^{\circ} \mathrm{C}$ to $70^{\circ} \mathrm{C}$, while the working $\mathrm{pH}$ ranged from 3.5 to 9.5 as shown in Figure $3 \mathrm{a}, \mathrm{b}$, respectively. According to Figure $3 \mathrm{a}$, the highest activity for both immobilized and free $\mathrm{MnP}$ was observed at $50{ }^{\circ} \mathrm{C}$, with values two times higher for the immobilized enzyme $(98 \pm 2 \%)$. This is related to the higher stability of the immobilized enzyme compared with the free enzyme. Generally, the interaction between the support and the enzyme makes the immobilized enzyme resistant to temperature variation. The difference in activity between the immobilized and free enzymes was reported by many researchers $[41,42]$. According to Figure $3 b$, there is no significant difference between the immobilized and free $\mathrm{MnP}$ activity over the $\mathrm{pH}$ range (4.0-8.0). However, at $\mathrm{pH}=8.5$, there is a significant difference between the activity of the immobilized and the free MnP. These results might be related to the changes of enzyme conformation associated with the microenvironment change and the formation of covalent bonds upon immobilization. Consequently, the immobilization process makes the enzyme stable and resistant to $\mathrm{pH}$ change as reported by many researchers $[43,44]$.

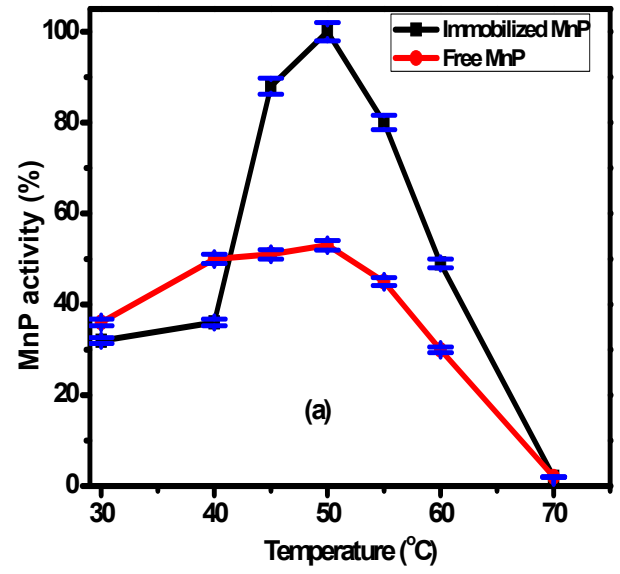

(a)

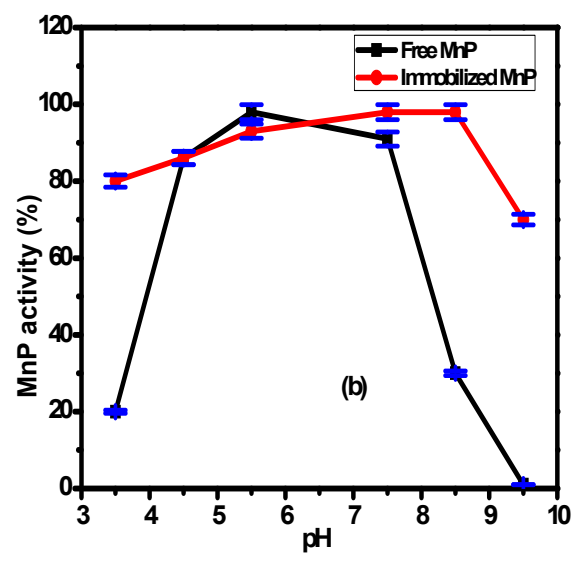

(b)

Figure 3. Cont. 


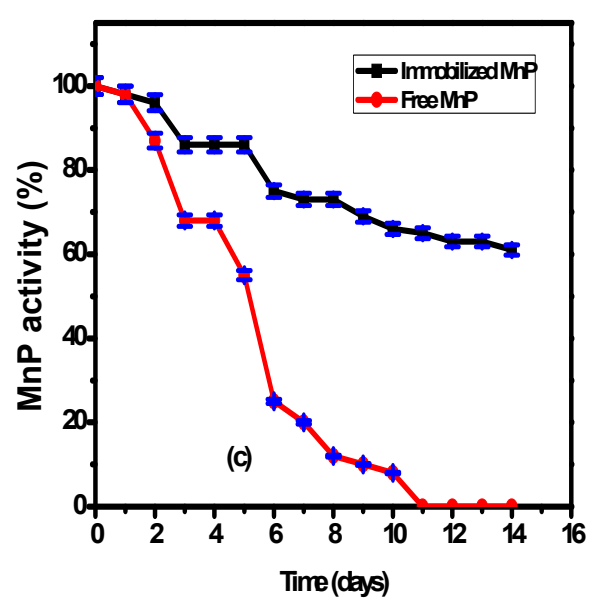

(c)

Figure 3. The effect of the operating parameters: (a) temperature, $(\mathbf{b}) \mathrm{pH}$, and (c) storage duration on free and immobilized MnP activity.

\subsection{The Effect of Storage Duration on Immobilized and Free MnP Activity}

The effect of storage at $20^{\circ} \mathrm{C}$ on the immobilized $\mathrm{MnP}$ on the surface of $\mathrm{Fe}_{3} \mathrm{O}_{4} /$ chitosan magnetic nanocomposite and on free $\mathrm{MnP}$ activities was studied over two weeks (Figure 3c). According to Figure 3c, there is higher stability of the immobilized MnP compared to the free enzyme during the storage period. The free enzyme showed $45 \pm 2 \%$ decrease of its activity during the first five days and $90 \pm 2 \%$ decrease after ten days. However, the immobilized MnP showed a slight decrease of its activity reaching $60 \pm 2 \%$ after 14 days. This behavior could be related to the presence of interactions between the enzyme and the nanocomposite support, which enhance the enzymatic stability compared to the free enzyme.

\subsection{Textile Wastewater Decolorization Using Mmobilized and Free MnP}

The removal efficiencies of $\mathrm{MB}$ and $\mathrm{RO} 16$ dyes using the $\mathrm{Fe}_{3} \mathrm{O}_{4} /$ chitosan nanocomposite, the free and the immobilized $\mathrm{MnP}$ enzyme on $\mathrm{Fe}_{3} \mathrm{O}_{4} /$ chitosan nanocomposite are shown in Figure $4 \mathrm{a}$,b. Experiments were conducted at $27^{\circ} \mathrm{C}$ and $\mathrm{pH} 7$, the values measured for the synthetic wastewater without any adjustment. Therefore, the operating conditions $\left(27^{\circ} \mathrm{C}\right.$ and $\left.\mathrm{pH} 7\right)$ that mimic the real environment are more logical for the application of the process at large scales. This could reduce the process cost at large scale. According to Figure $4 \mathrm{a}, \mathrm{b}$, free $\mathrm{MnP}$ allowed the removal of $40 \pm 2 \%$ and $43 \pm 2 \%$ of the MB and RO 16 after $10 \mathrm{~min}$, respectively. After $50 \mathrm{~min}$, the removal efficiency of $\mathrm{MB}$ and RO 16 reached $52 \pm 2 \%$ and $65 \pm 2 \%$, respectively. The obtained results indicate the advantages offered by the enzyme for the removal of organic pollutants from wastewater. Generally, enzymes are characterized by a notable efficiency and substrate specificity. Ligninolytic enzymes, especially $\mathrm{MnP}$, can degrade organic compounds, such as polyaromatic hydrocarbons, with high efficiency [36]. They act at different environmental conditions ( $\mathrm{pH}$, temperature, etc.), they are effective at low pollutant concentrations and they are not inhibited by xenobiotic and microbial inhibitors $[45,46]$. The results suggest that the problem associated with free enzymes can be reduced by the immobilization technology $[47,48]$. 


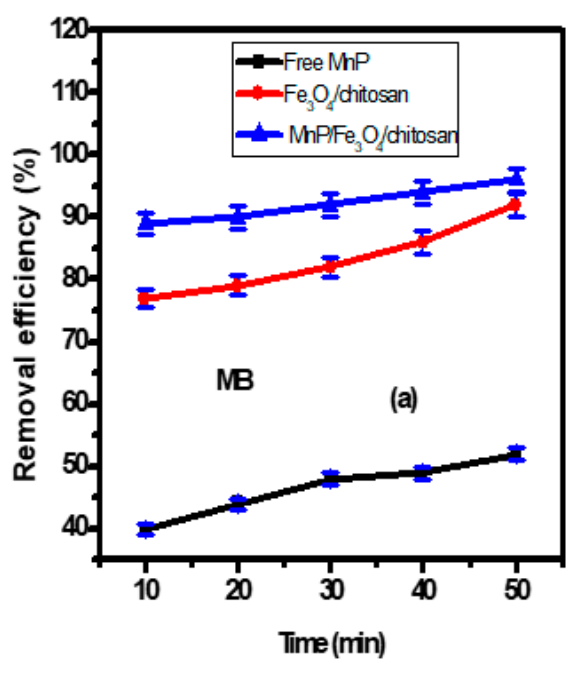

(a)

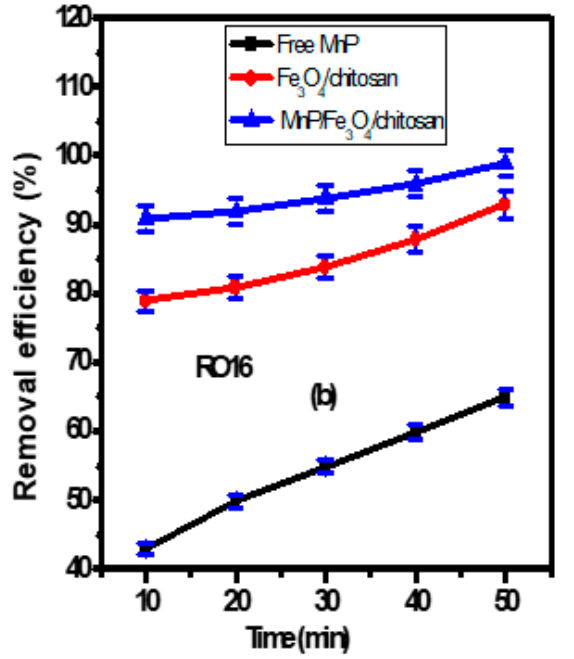

(b)

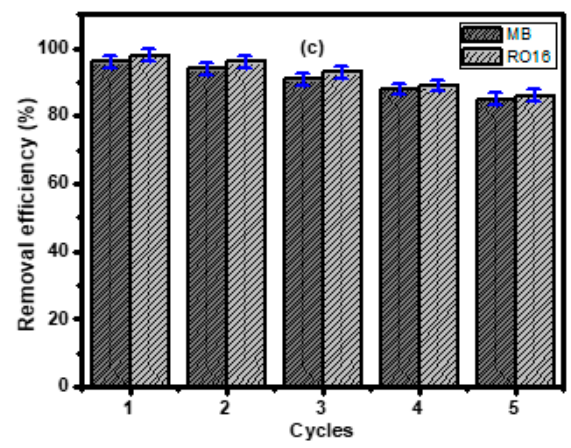

(c)

Figure 4. The removal of (a) MB and (b) RO 16 (dye initial concentration $=50 \mathrm{mg} / \mathrm{L}$ ) by using free $\mathrm{MnP}$, $\mathrm{Fe}_{3} \mathrm{O}_{4} /$ chitosan nanocomposite, $\mathrm{MnP} / \mathrm{Fe}_{3} \mathrm{O}_{4} /$ chitosan material; (c) the reusability of $\mathrm{MnP} / \mathrm{Fe}_{3} \mathrm{O}_{4} /$ chitosan for five cycles.

As illustrated in Figure $4 \mathrm{a}, \mathrm{b}$, the magnetic $\mathrm{Fe}_{3} \mathrm{O}_{4} /$ chitosan nanocomposite showed high removal efficiency for $\mathrm{MB}$ and $\mathrm{RO} 16$ of $77 \pm 2 \%$ and $79 \pm 2 \%$ after $10 \mathrm{~min}$, and these values reached $88 \pm 2 \%$ (for $\mathrm{MB}$ ) and $89 \pm 2 \%$ (for RO 16) after $50 \mathrm{~min}$, respectively. As shown in FT-IR bands (Figure 2a), the nanocomposite presents available adsorption sites, including amino and hydroxyl groups allowing an enhanced adsorption efficiency. The higher removal of both MB and RO 16 was obtained after $10 \mathrm{~min}$, due to the availability of active sites on the surfaces of nanocomposite that interact easily with a large number of dye molecules. After this period, only a few active sites remain available, explaining the slight enhancement of the adsorption at the end of the experiment (50 min). This fact has been investigated by many researchers $[49,50]$.

The magnetic $\mathrm{Fe}_{3} \mathrm{O}_{4}$ /chitosan nanocomposite was introduced in order to immobilize the MnP enzyme. After $50 \mathrm{~min}$, the immobilized enzyme allowed a decolorization rate of $96 \% \pm 2 \%$ and $98 \% \pm 2 \%$ for MB and RO 16, respectively (Figure 4a,b). Compared to the free enzyme, a significant improvement of the decolorization of textile wastewater was offered by the immobilized enzyme. The immobilization process increases the surface/volume ratio that enhances the binding capacity of the enzyme and helps to overcome the diffusion limitation [47]. Additionally, the small dimension of the enzyme carrier's nanoparticles can enhance the catalytic activity of the immobilized enzyme [48].

Compared to other studies, the prepared $\mathrm{Fe}_{3} \mathrm{O}_{4} /$ chitosan nanocomposite displayed higher $\mathrm{MB}$ removal efficiency than other nanomaterials, such as hausmannite [51], cryptomelane $\left(\alpha-\mathrm{MnO}_{2}\right)$ 
nanorods [52], and manganese oxide nanostructures [53]. Similarly, the obtained RO 16 removal efficiency was more efficient than modified zeolite [54], and humin immobilized on silica [55].

\subsection{The Reusability of $\mathrm{MnP} / \mathrm{Fe}_{3} \mathrm{O}_{4} /$ Chitosan Nanocomposite}

The reusability of $\mathrm{MnP} / \mathrm{Fe}_{3} \mathrm{O}_{4} /$ chitosan nanocomposite was examined due to its significant influence on the wastewater treatment processing cost, which is in part linked to the use of the nanocomposite. The nanocomposite reusability for the removal of MB and RO 16 was studied for successive five cycles as shown in Figure 4c. After each run, the magnetic nanocomposite was collected by a permanent magnet and washed many times to fit for the next run. After five cycles, the prepared $\mathrm{MnP} / \mathrm{Fe}_{3} \mathrm{O}_{4} /$ chitosan nanocomposite showed remarkable stability with slight decrease toward the removal of MB and RO 16 from wastewater. The removal efficiency of MB after cycle 1, 2, 3, 4, and 5 was $96 \pm 2 \%, 94 \pm 2 \%, 91 \pm 2 \%, 88 \pm 2 \%$, and $85 \pm 2 \%$, respectively. Likewise, the removal efficiency of RO 16 was $98 \pm 2 \%, 96 \pm 2 \%, 93 \pm 2 \%, 89 \pm 2 \%$, and $86 \pm 2 \%$ after cycle 1, 2, 3, 4, and 5, respectively. These features make the prepared $\mathrm{MnP} / \mathrm{Fe}_{3} \mathrm{O}_{4} /$ chitosan nanocomposite a promising means of $\mathrm{MB}$ and RO 16 removal from wastewater.

\section{Conclusions}

$\mathrm{Fe}_{3} \mathrm{O}_{4} /$ chitosan nanocomposite was an excellent support for the immobilization of MnP enzyme extracted from $A$. discolor. The produced material $\mathrm{MnP} / \mathrm{Fe}_{3} \mathrm{O}_{4} /$ chitosan was tested for decolorization of synthetic textile wastewater. Interestingly, the immobilized enzyme showed higher stability than the free enzyme at different operating conditions ( $\mathrm{pH}$, temperature, and storage duration). The prepared nanocomposite is considered as an ideal material with excellent properties as reported in the present study. For MB and RO 16, significant removal rates were achieved using the prepared nanocomposite. Moreover, the nanocomposite reusability was studied up to five cycles with ease recovery using a permanent magnet. However, more investigation is needed to explore other types of dyes under specific operating parameters ( $\mathrm{pH}$, temperature, etc.). The efficiency of this process should be studied for real textile wastewater and in real-world environmental conditions. Further, experiments using other enzymes should be conducted and the prepared nanocomposite could be explored for the bioremediation of other harmful pollutants.

Author Contributions: Conceptualization, F.B.R.; S.M.S., M.A.T., and W.M.; investigation, F.B.R.; data curation, F.B.R., M.A.T., and S.M.S.; writing-original draft preparation, F.B.R. and S.M.S.; writing-review and editing, W.M.; supervision, W.M.; project administration, F.B.R. and S.M.S. All authors have read and agreed to the published version of the manuscript.

Funding: This research was funded by Deanship of Scientific Research at King Khalid University.

Acknowledgments: The authors extended their appreciation to the Deanship of Scientific Research at King Khalid University for funding this work through Small Research Group Project under grant number R.G.P2/45/40.

Conflicts of Interest: The authors declare that there are no conflicts of interest regarding the publication of this article.

\section{References}

1. Siddeeg, S.M.; Tahoon, M.A.; Ben Rebah, F. Simultaneous Removal of Calconcarboxylic Acid, $\mathrm{NH}_{4}{ }^{+}$and $\mathrm{PO}_{4}{ }^{3-}$ from Pharmaceutical Effluent Using Iron Oxide-Biochar Nanocomposite Loaded with Pseudomonas putida. Processes 2019, 7, 800. [CrossRef]

2. Hamdaoui, O.; Chiha, M. Removal of methylene blue from aqueous solutions by wheat bran. Acta Chim. Slov. 2007, 54, 407-418.

3. Marrakchi, F.; Ahmed, M.J.; Khanday, W.A.; Asif, M.; Hameed, B.H. Mesoporous-activated carbon prepared from chitosan flakes via single-step sodium hydroxide activation for the adsorption of methylene blue. Int. J. Biol. Macromol. 2017, 98, 233-239. [CrossRef] [PubMed] 
4. Islam, M.A.; Sabar, S.; Benhouria, A.; Khanday, W.A.; Asif, M.; Hameed, B.H. Nanoporous activated carbon prepared from karanj (Pongamia pinnata) fruit hulls for methylene blue adsorption. J. Taiwan Inst. Chem. Eng. 2017, 74, 96-104. [CrossRef]

5. Ayad, M.M.; Abu El-Nasr, A. Adsorption of Cationic Dye (Methylene Blue) from Water Using Polyaniline Nanotubes Base. J. Phys. Chem. C 2010, 114, 14377-14383. [CrossRef]

6. Pandiselvi, K.; Thambidurai, S. Synthesis of porous chitosan-polyaniline/ZnO hybrid composite and application for removal of reactive orange 16 dye. Colloids Surf. B Biointerfaces 2013, 108, 229-238.

7. Spadaro, J.T.; Gold, M.H.; Renganathan, V. Degradation of azo dyes by the lignin-degrading fungus Phanerochaete chrysosporium. Appl. Environ. Microbiol. 1992, 58, 2397-2401.

8. Lu, K.; Zhang, X.L.; Zhao, Y.L.; Wu, Z.L. Removal of color from textile dyeing wastewater by foam separation. J. Hazard. Mater. 2010, 182, 928-932. [CrossRef]

9. Yang, D.; Lingbing, Q.; Yang, Y. Efficient adsorption of methyl orange using a modified chitosan magnetic composite adsorbent. J. Chem. Eng. Data 2016, 63, 147-158. [CrossRef]

10. Fu, F.; Wang, Q. Removal of heavy metal ions from wastewater: A review. J. Environ. Manag. 2011, 92, 407-418. [CrossRef]

11. Nataraj, S.K.; Hosamani, K.M.; Ainabhavi, T.M. Nanofiltration and reverse osmosis thin film composite membrane module for the removal of dye and salts from the simulated mixtures. Desalination 2009, 249, 12-17. [CrossRef]

12. Xiong, W.; Zeng, G.; Yang, Z.; Zhou, Y.; Zhang, C.; Cheng, M.; Liu, Y.; Hu, L.; Wan, J.; Zhou, C.; et al. Adsorption of tetracycline antibiotics from aqueous solutions on nanocomposite multi-walled carbon nanotube functionalized MIL-53(Fe) as new adsorbent. Sci. Total Environ. 2018, 627, 235-244. [CrossRef] [PubMed]

13. Lau, W.J.; Ismail, A.F. Polymeric nanofiltration membranes for textile dye wastewater treatment: Preparation, performance evaluation, transport modelling, and fouling control—A review. Desalination 2009, 245, 321-348. [CrossRef]

14. Santos, S.C.; Boaventura, R.A. Treatment of a simulated textile wastewater in a sequencing batch reactor (SBR) with addition of a low-cost adsorbent. J. Hazard. Mater. 2015, 291, 74-82. [CrossRef] [PubMed]

15. Pathania, D.; Gupta, D.; Al-Muhtaseb, A.H.; Sharma, G.; Kumar, A.; Naushad, M.; Ahamad, T.; Alshehri, S.M. Photocatalytic degradation of highly toxic dyes using chitosan-g-poly(acrylamide)/ZnS in presence of solar irradiation. J. Photochem. Photobiol. A Chem. 2016, 329, 61-68. [CrossRef]

16. Ben Rebah, F.; Mnif, W.; Siddeeg, S.M. Microbial Flocculants as an Alternative to Synthetic Polymers for Wastewater Treatment: A Review. Symmetry 2018, 10, 556. [CrossRef]

17. Xiong, W.; Zeng, Z.; Li, X.; Zeng, G.; Xiao, R.; Yang, Z.; Zhou, Y.; Zhang, C.; Cheng, M.; Hu, L.; et al. Multi-walled carbon nanotube/amino-functionalized MIL-53(Fe) composites: Remarkable adsorptive removal of antibiotics from aqueous solutions. Chemosphere 2018, 210, 1061-1069. [CrossRef]

18. Zhou, C.; Lai, C.; Xu, P.; Zeng, G.; Huang, D.; Zhang, C.; Cheng, M.; Hu, L.; Wan, J.; Liu, Y.; et al. In Situ Grown $\mathrm{AgI} / \mathrm{Bi}_{12} \mathrm{O}_{17} \mathrm{Cl}_{2}$ Heterojunction Photocatalysts for Visible Light Degradation of Sulfamethazine: Efficiency, Pathway, and Mechanism. ACS Sustain. Chem. Eng. 2018, 6, 4174-4184. [CrossRef]

19. Pansini, M.; Sannino, F.; Marocco, A.; Allia, P.; Tiberto, P.; Barrera, G.; Polisi, M.; Battista, E.; Netti, P.A.; Esposito, S. Novel process to prepare magnetic metal-ceramic nanocomposites from zeolite precursor and their use as adsorbent of agrochemicals from water. J. Environ. Chem. Eng. 2018, 6, 527-538. [CrossRef]

20. Shakerian, F.; Zhao, J.; Li, S.P. Recent development in the application of immobilized oxidative enzymes for bioremediation of hazardous micropollutants-A review. Chemosphere 2020, 239, 124716. [CrossRef]

21. Jun, L.Y.; Yon, L.S.; Mubarak, N.M.; Bing, C.H.; Pan, S.; Danquah, M.K.; Abdullah, E.C.; Khalid, M. An overview of immobilized enzyme technologies for dye, phenolic removal from wastewater. J. Environ. Chem. Eng. 2019, 7, 102961. [CrossRef]

22. Bilal, M.; Rasheed, T.; Zhao, Y.; Iqbal, H.M. Agarose-chitosan hydrogel-immobilized horseradish peroxidase with sustainable bio-catalytic and dye degradation properties. Int. J. Biol. Macromol. 2019, 124, 742-749. [CrossRef] [PubMed]

23. Premaratne, G.; Nerimetla, R.; Matlock, R.; Sunday, L.; Koralege, R.S.H.; Ramsey, J.D.; Krishnan, S. Stability, scalability, and reusability of a volume efficient biocatalytic system constructed on magnetic nanoparticles. Catal. Sci. Technol. 2016, 6, 2361-2369. [CrossRef] [PubMed] 
24. Krishnan, S.; Goud, K.Y. Magnetic Particle Bioconjugates: A Versatile Sensor Approach. Magnetochemistry 2019, 5, 64. [CrossRef]

25. Nerimetla, R.; Premaratne, G.; Liu, H.; Krishnan, S. Improved electrocatalytic metabolite production and drug biosensing by human liver microsomes immobilized on amine-functionalized magnetic nanoparticles. Electrochim. Acta 2018, 280, 101-107. [CrossRef]

26. Li, X.; He, Y.; Sui, H.; He, L. One-step fabrication of dual responsive lignin coated $\mathrm{Fe}_{3} \mathrm{O}_{4}$ nanoparticles for efficient removal of cationic and anionic dyes. Nanomaterials 2018, 8, 162. [CrossRef]

27. Lee, S.Y.; Shim, H.E.; Yang, J.E.; Choi, Y.J.; Jeon, J. Continuous Flow Removal of Anionic Dyes in Water by Chitosan-Functionalized Iron Oxide Nanoparticles Incorporated in a Dextran Gel Column. Nanomaterials 2019, 9, 1164. [CrossRef]

28. Zhou, Y.; Pan, S.; Wei, X.; Wang, L.; Liu, Y. Immobilization of $\beta$-glucosidase onto magnetic nanoparticles and evaluation of the enzymatic properties. BioResources 2013, 8, 2605-2619. [CrossRef]

29. Zheng, X.; Zheng, H.; Zhao, R.; Sun, Y.; Sun, Q.; Zhang, S.; Liu, Y. Polymer-functionalized magnetic nanoparticles: Synthesis, characterization, and methylene blue adsorption. Materials 2018, 11, 1312. [CrossRef]

30. Scialla, S.; Barca, A.; Palazzo, B.; D’Amora, U.; Russo, T.; Gloria, A.; De Santis, R.; Verri, T.; Sannino, A.; Ambrosio, L.; et al. Bioactive chitosan-based scaffolds with improved properties induced by dextran-grafted nano-maghemite and l-arginine amino acid. J. Biomed. Mater. Res. Part A 2019, 107, 1244-1252. [CrossRef]

31. Ngah, W.S.W.; Teong, L.C.; Hanafiah, M.A.K.M. Adsorption of dyes and heavy metal ions by chitosan composites: A review. Carbohydr. Polym. 2011, 83, 1446-1456. [CrossRef]

32. Bhatnagar, A.; Sillanpaa, M. Applications of chitin and chitosan derivates for the detoxifications of water and wastewater-A short review. Adv. Colloid Interf. Sci. 2009, 152, 26-38. [CrossRef] [PubMed]

33. Wu, F.C.; Tseng, R.L.; Juang, R.S. A review and experimental verification of using chitosan and its derivates as adsorbents for selected heavy metals. Adv. Colloid Interf. Sci. 2010, 91, 798-806.

34. Eibes, G.; Cajthaml, T.; Moreira, M.T.; Feijoo, G.; Lema, J.M. Enzymatic degradation of anthracene, dibenzothiophene and pyrene by manganese peroxidase in media containing acetone. Chemosphere 2006, 64, 408-414. [CrossRef] [PubMed]

35. Bogan, B.L.; Lamar, R.T. One-electron oxidation in the degradation of creosote polycyclic aromatic hydrocarbons by Phanerochaete chrysosporium. Appl. Environ. Microbiol. 1995, 61, 2631-2635.

36. Baborová, P.; Möder, M.; Baldrian, P.; Cajthamlová, K.; Cajthaml, T. Purification of a new manganese peroxidase of the white-rot fungus Irpex lacteus, and degradation of polycyclic aromatic hydrocarbons by the enzyme. Res. Microbiol. 2006, 157, 248-253. [CrossRef]

37. Torres, E.; Bustos-Jaimes, I.; Le Borgne, S. Potential use of oxidative enzymes for the detoxification of organic pollutants. Appl. Catal. B 2003, 46,1-15. [CrossRef]

38. Castillo, M.D.; Strenström, J.; Ander, P. Determination of manganese peroxidase activity with 3-methyl-2-benzothiazolinone hydrazone and 3- (dimethylamino) benzoic acid. Anal. Biochem. 1994, 218, 399-404. [CrossRef]

39. Srivastava, M.; Singh, J.; Yashpal, M.; Gupta, D.K.; Mishra, R.; Tripathi, S.; Ojha, A.K. Synthesis of superparamagnetic bare $\mathrm{Fe}_{3} \mathrm{O}_{4}$ nanostructures and core/shell $\left(\mathrm{Fe}_{3} \mathrm{O}_{4} /\right.$ alginate) nanocomposites. Carbohydr. Polym. 2012, 89, 821-829. [CrossRef]

40. Li, W.; Xiao, L.; Qin, C.Q. The characterization and thermal investigation of chitosanFe $\mathrm{O}_{4}$ nano-particles synthesized via a novel one-step modifying process. J. Macromol. Sci. A 2011, 48, 57-64. [CrossRef]

41. Lante, A.; Crapisi, A.; Krastanov, A.; Spettoli, P. Biodegradation of phenols by laccase immobilised in a membrane reactor. Process Biochem. 2000, 36, 51-58. [CrossRef]

42. Kunamneni, A.; Ghazi, I.; Camarero, S.; Ballesteros, A.; Plou, F.J.; Alcalde, M. Decolorization of synthetic dyes by laccase immobilized on epoxy-activated carriers. Process Biochem. 2008, 43, 169-178. [CrossRef]

43. Altinok, H.; Aksoy, S.; Tümtürk, H.; Hasirci, N. Covalent immobilization of invertase on chemically activated poly (2-hydroxyethyl methacrylate) microbeads. Russ. Chem. Bull. 2006, 55, 1860-1864. [CrossRef]

44. Chiou, S.H.; Wu, W.T. Immobilization of Candida rugosa lipase on chitosan with activation of the hydroxyl groups. Biomaterials 2004, 25, 197-204. [CrossRef]

45. Gianfreda, L.; Rao, M.A. Potential of extracellular enzymes in relation of polluted soils: A review. Enzyme Microb. Technol. 2004, 33, 339-354. [CrossRef] 
46. Quiquampoix, H.; Servagent-Noinville, S.; Baron, M.H. Enzyme adsorption on soil mineral surfaces and consequences for the catalytic activity. In Enzymes in the Environment; Marcel Dekker: New York, NY, USA, 2002; pp. 285-306.

47. Oh, J.T.; Kim, J.H. Preparation and properties of immobilized amyloglucosidase on nonporous PS/PNaSS microspheres. Enzyme Microb. Technol. 2000, 27, 356-361. [CrossRef]

48. Hu, X.; Zhao, X.; Hwang, H.M. Comparative study of immobilized Trametes versicolor laccase on nanoparticles and kaolinite. Chemosphere 2007, 66, 1618-1626. [CrossRef]

49. Abukhadra, M.R.; Dardir, F.M.; Shaban, M.; Ahmed, E.A.; Soliman, M.F. Superior removal of $\mathrm{Co}^{2+}, \mathrm{Cu}^{2+}$ and $\mathrm{Zn}^{2+}$ contaminants from water utilizing spongy Ni/Fe carbonate-fluorapatite; preparation, application and mechanism. Ecotoxicol. Environ. Saf. 2018, 157, 358-368. [CrossRef]

50. Shaban, M.; Abukhadra, M.R.; Mohamed, A.S.; Shahien, M.G.; Ibrahim, S.S. Synthesis of Mesoporous Graphite Functionalized by Nitrogen for Efficient Removal of Safranin Dye Utilizing Rice Husk Ash; Equilibrium Studies and Response Surface Optimization. J. Inorg. Organomet. Polym. 2018, 28, $279-294$. [CrossRef]

51. Wang, Y.; Zhu, L.; Yang, X.; Shao, E.; Deng, X.; Liu, N.; Wu, M. Facile synthesis of three-dimensional $\mathrm{Mn}_{3} \mathrm{O}_{4}$ hierarchical microstructures and their application in the degradation of methylene blue. J. Mater. Chem. A 2015, 3, 2934-2941. [CrossRef]

52. Cao, G.; Su, L.; Zhang, X.; Li, H. Hydrothermal synthesis and catalytic properties of $\alpha$-and $\beta-\mathrm{MnO}_{2}$ nanorods. Mater. Res. Bull. 2010, 45, 425-428. [CrossRef]

53. Chen, H.; He, J. Facile synthesis of monodisperse manganese oxide nanostructures and their application in water treatment. J. Phys. Chem. C 2008, 112, 17540-17545. [CrossRef]

54. Fungaro, D.A.; Borrely, S.I.; Carvalho, T.E. Surfactant modified zeolite from cyclone ash as adsorbent for removal of Reactive Orange 16 from aqueous solution. Am. J. Environ. Prot. 2013, 1, 1-9. [CrossRef]

55. Jesus, A.M.D.; Romao, L.P.C.; Araújo, B.R.; Costa, A.S.; Marques, J.J. Use of humin as an alternative material for adsorption/desorption of reactive dyes. Desalination 2011, 274, 13-21. [CrossRef]

(C) 2019 by the authors. Licensee MDPI, Basel, Switzerland. This article is an open access article distributed under the terms and conditions of the Creative Commons Attribution (CC BY) license (http://creativecommons.org/licenses/by/4.0/). 